\title{
Malignant histiocytosis of the intestine: report of three cases with immunological and cytochemical analysis
}

\author{
P ISAACSON, DB JONES, MJ SWORN, DH WRIGHT \\ From the Department of Pathology, Southampton University Medical School, Southampton SO9 $4 X Y$
}

SUMMARY Tumour cells from three cases of malignant histiocytosis of the intestine (MHI) have been studied immunologically and cytochemically. The cells did not form E rosettes and showed weak Fc $\gamma$ surface receptors. They contained non-specific esterase and acid phosphatase in diffuse granular distribution. In one case tumour cells showed no staining by an immunoperoxidase technique with two monoclonal anti-T cell antibodies but positive staining with a monoclonal anti-Ia-like antibody. The malignant cells from all three cases could be shown to contain alpha-1-antitrypsin. These are the first cases of MHI to have been studied in this way and the results confirm the true histiocytic - that is, monocyte/macrophage, derivation of the tumour cells in this disease.

In 1978 Isaacson and Wright first suggested that primary gastrointestinal lymphoma complicating coeliac disease was a specific histopathological entity. ${ }^{12}$ In their view the great majority, if not all, of these cases which had been variously labelled Hodgkin's disease, reticulum cell sarcoma and immunoblastic sarcoma were a variant of malignant histiocytosis which appeared to arise in the intestine. They called this disease malignant histiocytosis of the intestine (MHI) to distinguish it from the classical form of malignant histiocytosis as defined by Byrne and Rappaport. ${ }^{3}$ In view of the immunological setting in which the disease occurs and the wide variation in both its macroscopic and microscopic appearances others have found this concept difficult to accept. ${ }^{4}$ Central to this controversy is the precise characterisation of the malignant cells. Given the nature of these cases which often present as surgical abdominal emergencies or with other features which are not necessarily suggestive of lymphoma, it has proved difficult to obtain unfixed tissue for histogenetic studies. A recent opportunity to obtain fresh tissue from three such cases has, for the first time, permitted us to carry out a detailed study of the immunological, immunohistochemical and cytochemical properties of the malignant cells comprising the disease we call MHI.

Accepted for publication 7 October 1981

\section{Case reports}

CASE 1

A 46-year-old man who had had intermittent diarrhoea for four years was admitted complaining of severe diarrhoea of six weeks duration accompanied by a $15 \mathrm{lb}(6.8 \mathrm{~kg})$ weight loss. On examination there was clubbing of the fingers and dehydration but no other abnormality and specifically no lymphadenopathy or hepatosplenomegaly. Laboratory investigations revealed a haemoglobin of $13.2 \mathrm{~g} / \mathrm{dl}$ with normal white cell and platelet counts. Lactic dehydrogenase was 161 IU/1 (normal 30-90), alkaline phosphatase 138 IU/1 (normal 20-90) and albumin $29 \mathrm{~g} / 1$ (normal 35-47). Serum calcium was

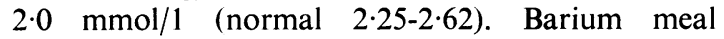
suggested neoplastic infiltration of the small intestine and a laparotomy was performed. At laparotomy the small bowel was flaccid and atrophic in appearance and showed brown discolouration proximally. There was no other abnormality noted and full thickness biopsies of jejunum and ileum were taken. The biopsies showed the characteristic changes of coeliac disease with villous atrophy maximal in the jejunum. The "early lesions"5 of malignant histiocytosis of the intestine (MHI) were present. Bone marrow aspirate showed malignant histiocytes some of which showed haemophagocytosis. The patient was started on a gluten-free diet with dramatic 
remission of his diarrhoea and peroral jujenal biopsy six weeks after the laparotomy showed marked improvement of villous architecture and reduction in lamina propria plasma cells. After this initial improvement the patient developed swinging pyrexia followed by generalised lymphadenopathy. A cervical lymph node biopsy was performed two months after admission and submitted fresh to the laboratory. He was then started on chemotherapy.

\section{CASE 2}

A 66-year-old woman presented with upper small intestinal obstruction in 1979. She had a 27 -year history of intermittent iron deficiency anaemia. Laboratory investigations were normal apart from a haemoglobin of $10 \mathrm{~g} / \mathrm{dl}$ with microcytosis of red cells. At laparotomy a stricture with two adjacent tumour nodules was identified $25 \mathrm{~cm}$ from the duodenojejunal junction and this was resected together with enlarged mesenteric lymph nodes. Pathological diagnosis was malignant histiocytosis of the intestine. The patient made a good postoperative recovery but refused any further investigations or treatment. She remained reasonably well for two years after the initial surgery but was then readmitted with a one-month history of diarrhoea, abdominal pain and distention. Ascites was noted on examination and malignant cells were identified in the ascitic fluid. A barium meal showed a perforation in the upper duodenum. At laparotomy there was diffuse peritonitis with a perforation of the duodenum. The duodenal perforation was biopsied and oversewn and biopsies were taken of large, haemorrhagic, mesenteric lymph nodes and submitted fresh to the laboratory. The patient steadily deteriorated and died nine days after operation. A post-mortem was performed.

\section{CASE 3}

A 53-year-old man with a five-year history of intermittent diarrhoea was admitted complaining of anorexia and malaise of five months duration accompanied by a $14 \mathrm{lb}(6.24 \mathrm{~kg})$ weight loss. Examination revealed a lower abdominal mass. Pertinent laboratory investigations included a haemoglobin of $10 \cdot 3 \mathrm{~g} / \mathrm{dl}$ with normal white cell and platelet counts and liver function tests which were grossly deranged. At laparotomy there were multiple tumour nodules in the small intestine with a large stricturing mass of the distal ileum accompanied by enlarged mesenteric lymph nodes. This mass was resected and a liver biopsy performed. Histology showed MHI with liver involvement. The patient made a good postoperative recovery and subsequent bone marrow aspirate and trephine were normal. A peroral jejunal biospy showed villous atrophy. Chemotherapy was commenced with dramatic improvement which was sustained for six months. The patient then deteriorated with recurrence of intra-abdominal disease and the appearance of overwhelming numbers of malignant cells in the bone marrow, an aspirate of which was submitted fresh to the laboratory. The disease was no longer responsive to chemotherapy and the patient died after a hypotensive episode. A post-mortem was performed.

\section{Material and methods}

Sections of formalin-fixed paraffin-embedded tissue from all three cases were examined using routine histopathological stains and the PAP immunoperoxidase technique after trypsin treatment. The antigens stained for included the three major Ig heavy chains, $\kappa \& \lambda$ light chains, $\mathrm{J}$ chain, lysozyme and alpha-1-antitrypsin $\left(\alpha_{1}-\mathrm{AT}\right)$. Details of the methods used, and controls, have been previously described. ${ }^{6-8}$

Frozen sections of lymph node from case 1 were acetone-fixed and stained by the method of Stein ${ }^{9}$ with monoclonal antibodies directed towards T lymphocytes (UCH T1 ${ }^{10}$ and $\mathrm{S} 33$, unpublished, gifts from Dr $\mathbf{P}$ Beverly, ICRF Human Tumour Immunology Unit, University College, London) and with DA-2, ${ }^{11}$ a monoclonal antibody directed towards a non-polymorphic determinant of HLA-DR (generously provided by $\mathrm{Dr} \mathrm{M}$ Crumpton, ICRF, Lincoln's Inn Fields, London).

Fresh lymph node biopsy tissue from cases 1 and 2 was finely minced in RPMI 1640 containing $10 \%$ fetal serum and bone marrow aspirate from case 3 was collected in the same medium. Mononuclear cells from the three cases were prepared by centrifugation through ficoll-triosil as described previously. ${ }^{12}$ All marker tests were performed on the washed mononuclear cells and rosetted preparations were cytocentrifuged and stained to permit the identification of neoplastic cells. Detailed rosetting techniques have been described eleswhere. ${ }^{13}$ Briefly, mononuclear cells were rosetted with washed sheep red blood cells (RBC) at $37^{\circ} \mathrm{C}$ followed by a period on ice (E rosettes) or assayed for receptors for the $\mathrm{Fc}$ portion of $\operatorname{IgG}(\mathrm{Fc} \gamma)$ and $\operatorname{IgM}(\mathrm{Fc} \mu)$ by rosetting with appropriately sensitised ox RBC. Ox cells were sensitised with a subagglutinating dose of an $\operatorname{IgM}$ or IgG fraction of a rabbit anti-ox RBC serum prepared in this laboratory. To facilitate the reaction Fc rosetting was carried out on cells that had been incubated at $37^{\circ} \mathrm{C}$ overnight in the absence of human serum. Viable cells from cases 1 and 3 were stained for surface immunoglobulins (sIg) using a FITC-conjugated rabbit antiserum to polyclonal 
human immunoglobulins (kindly provided by Professor GT Stevenson of the Tenovus Research Laboratory, Southampton General Hospital).

Rosetted and unrosetted cytocentrifuge preparations were fixed for the demonstration of nonspecific esterase (NSE) and ASD chloracetate esterase by immersion in formol acetone for $30 \mathrm{~s}$ followed by a water rinse and for acid phosphatase by fixation in formalin vapour. The three enzyme activities were demonstrated by the method of Yam et al $^{14}$ and Hayhoe ${ }^{15}$ respectively. In cases 2 and 3 staining for NSE was performed both with and without sodium fluoride $(\mathrm{NaF})$ inhibition.

\section{Results}

The immunological, cytochemical and immunohistochemical results are summarised in the Table.

PATHOLOGICAL OBSERVATIONS

The operative small intestinal biopsies in case 1 showed severe villous atrophy and crypt hyperplasia of the jejunum with similar, but less marked changes, in the ileum. Brown pigment was present in the muscle cells of the jejunum and in both biopsies characteristic early lesions of MHI were evident in the form of destroyed crypts with surrounding histiocytic aggregates. ${ }^{5}$ The cervical lymph node was replaced by a pleomorphic large cell lymphoma with numerous multinucleated cells (Fig. 1).

In case 2 the intestinal lymphoma initially resected consisted of sheets of primitive, rather monomorphic, cells with little cytoplasm and nuclei containing large prominent nucleoli (Fig. 2). Uninvolved intestine showed villous atrophy and crypt hyperplasia with focal early lesions similar to those described in case 1. Tumour cells infiltrated the sinuses of the mesenteric lymph nodes. Biopsies from the duodenal perforation taken at the second laparotomy showed villous atrophy and crypt hyperplasia of the mucosa and non-specific chronic inflammation in the ulcer edges and base. The resected lymph nodes showed foci of haemorrhagic necrosis and the characteristic sinusoidal infiltrate of malignant histiocytosis. At necropsy there was peritonitis and

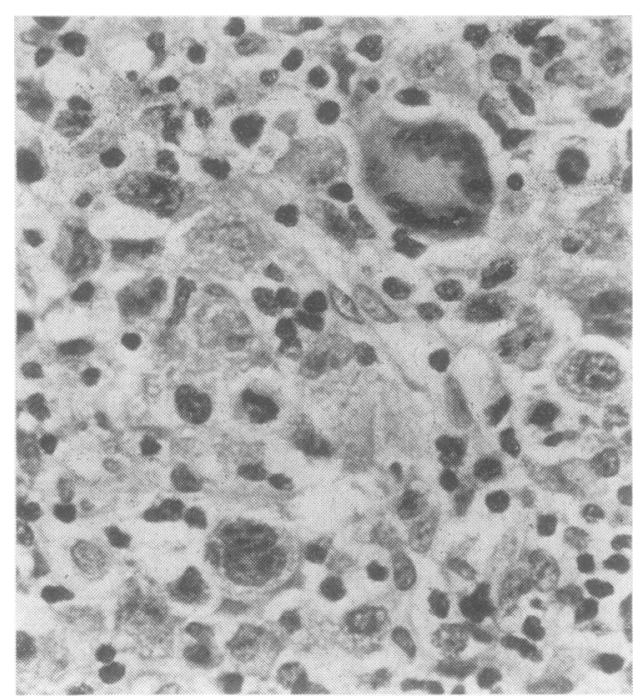

Fig. 1 Case 1: section of lymph node showing sheets of large pleomorphic malignant histiocytes and interspersed small lymphocytes. Haematoxylin and $\operatorname{cosin} \times 40()$

bronchopneumonia with widespread infiltration of tissues by non-adherent pleomorphic malignant cells, many of which showed erythrophagocytosis. Intrasinusoidal infiltrates were present in lymph nodes, spleen, liver and adrenal glands and malignant cells were also seen in bone marrow smears.

The intestinal tumour in case 3 consisted of sheets of large cells with abundant cytoplasm and nuclei containing prominent nucleoli (Fig. 3). Tumour cells replaced mesenteric lymph nodes and infiltrated the sinusoids of the liver. The bone marrow aspirate, obtained shortly before death, consisted almost entirely of malignant cells. At post-mortem there was a large mass of tumour in the small bowel mesentery and an enlarged liver $(2150 \mathrm{~g})$ and moderately enlarged spleen $(285 \mathrm{~g})$. Histology showed characteristic infiltrates of non-adherent tumour cells in mesenteric lymph nodes, liver sinusoids and spleen.

Properties of tumour cells from three cases of $\mathrm{MHI}$

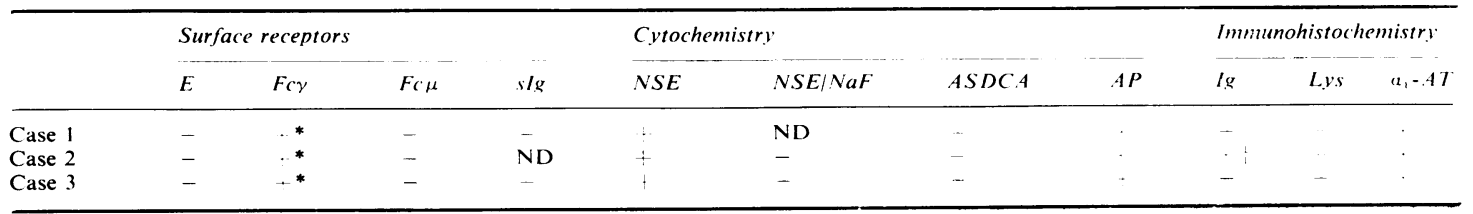

$\mathrm{E}=\mathrm{E}$ rosettes. ASDCA $=$ ASD chloracetate esterase. AP acid phosphatase,

Lys lysozyme. ${ }^{*}$ weakly positive. polytypic IgG. 


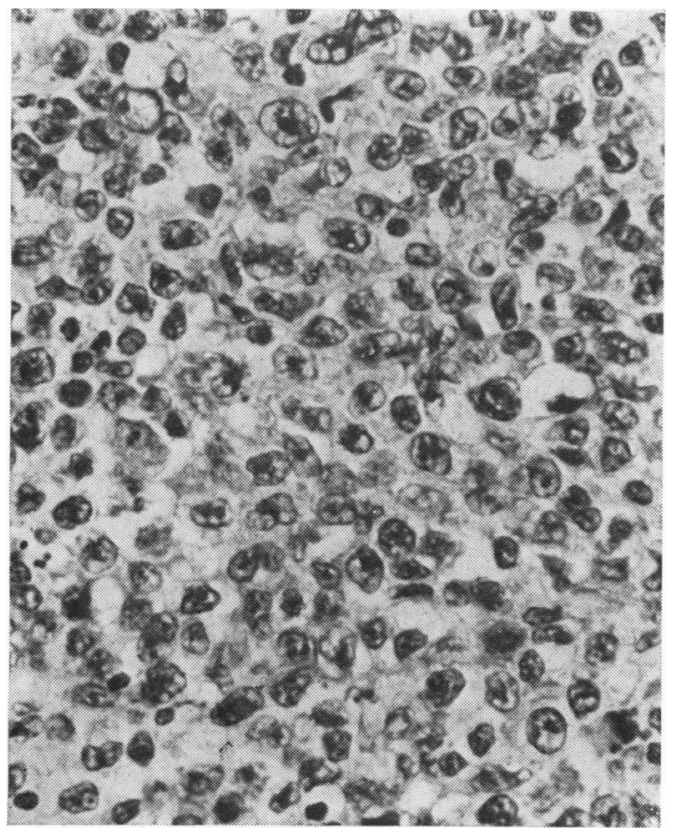

Fig. 2 Case 2: section of intestinal tumour showing relatively monomorphic tumour cells with large vesicular indented nuclei containing prominent nucleoli. There is relatively little cytoplasm. Haematoxylin and eosin $\times 400$

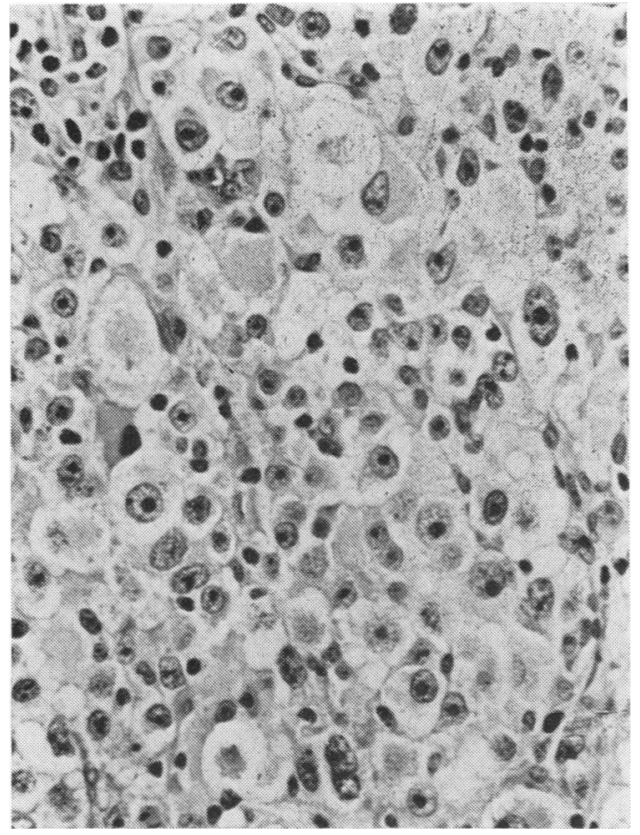

Fig. 3 Case 3: section of intestinal tumour consisting predominantly of cells with abundant cytoplasm and nuclei with prominent and centrally situated neuleoli. Haematoxylin and eosin $\times 400$
INVESTIGATION OF SURFACE RECEPTORS

In cases 1 and 3 tumour cells demonstrated no surface immunoglobulin after incubation for $24 \mathrm{~h}$. The malignant cells of all cases did not form $\mathrm{E}$ rosettes but showed weak rosetting with IgGcoated ox cells (Fig. 4). There was no rosetting with IgM-coated ox cells and no phagocytic activity was demonstrated.

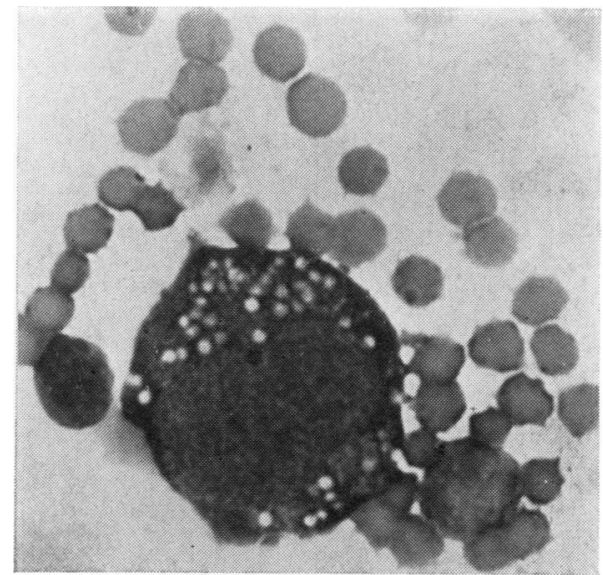

Fig. 4 Case 1: tumour cell showing rosetting with IgG coated ox RBC Wright-Giemsa $\times 1000$

CYTOCHEMISTRY

The tumour cells of all cases stained positively for NSE and in cases 2 and 3 this positive staining was inhibited by $\mathrm{NaF}$ (Fig. 5). Stains for ASD chloracetate esterase were negative, while stains for acid phosphatase were positive (Fig. 6).

IMMUNOHISTOCHEMISTRY

The tumour cells in case 1 were shown to contain polytypic IgG ( $\kappa$ and $\lambda$ chains present) while those in the other two cases were negative for all immunoglobulins. The cells in all three cases were negative for $\mathbf{J}$ chain and lysozyme but stained positively for $\alpha_{1}$-AT with characteristic granular staining often tucked into the nucleus (Fig. 7).

Frozen sections of case 1 showed positive staining of the surface of large numbers of lymphocytes with monoclonal antisera to T cells (UCH T1 \& S33) while tumour cells were negative. Monoclonal antiserum to HLA DR (DA 2) stained numerous cells in the sections including obvious pleomorphic tumour cells.

\section{Discussion}

Previous studies of fresh material from cases of MHI have been limited to histochemical staining of 


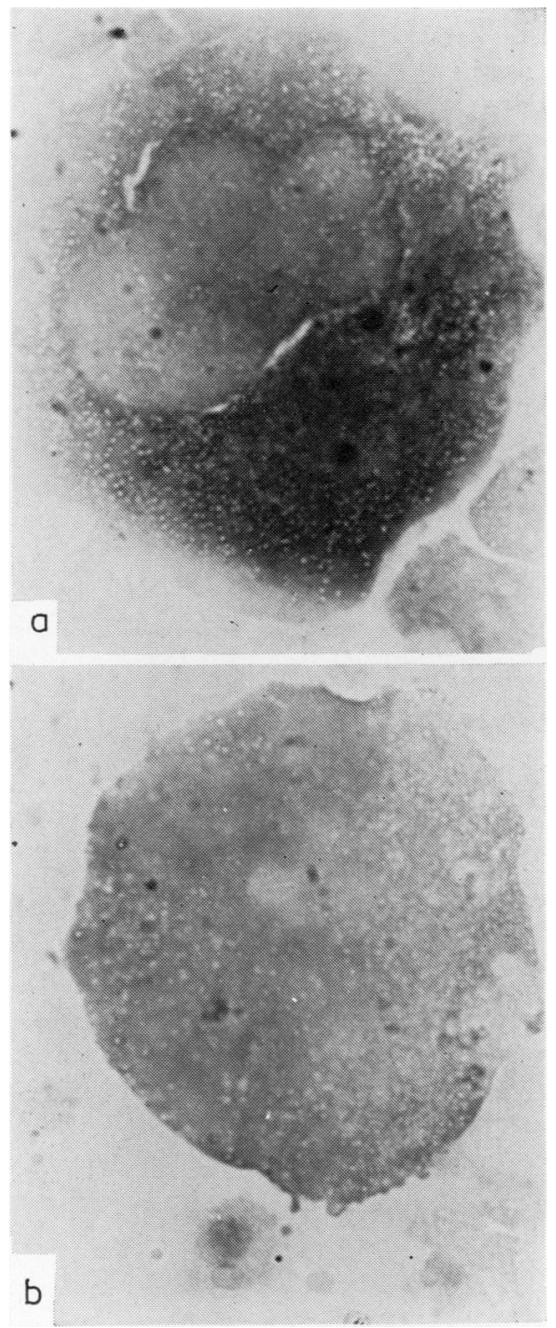

Fig. 5 Case 3: cytocentrifuge preparation stained for non-specific esterase (a) without and (b) with $\mathrm{NaF}$ inhibition. There is diffuse staining of a large tumour cell which is inhibited by NaF. Esterase $\times 1000$

frozen sections. ${ }^{2}$ These studies, which showed NSE and acid phosphatase in tumour cells of three cases did not entirely exclude the possibility of a $T$ cell origin of these malignancies since $T$ cells can show cytochemical reactions similar to histiocytes. ${ }^{16}$ $\mathrm{T}$ cells may also show $\mathrm{Fc} \gamma$ surface receptors ${ }^{16}$ and a recent report of two cases of $\mathrm{T} \gamma$ cell lymphoma mimicking malignant histiocytosis morphologically ${ }^{17}$ further emphasises the pitfalls in the diagnosis of histiocytic malignancies. The malignant cells in these two cases, however, formed $\mathrm{E}$ rosettes and showed $\mathrm{T}$ cell cytochemical reactions. There can be little

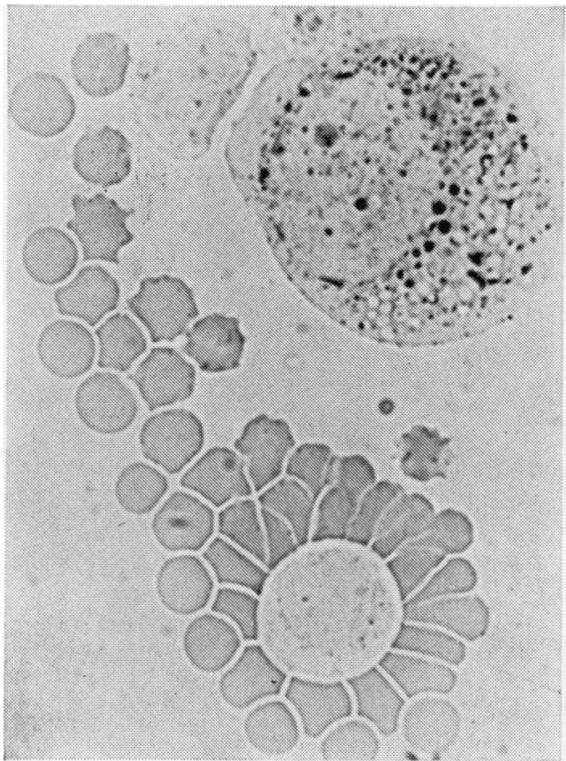

Fig. 6 Case 1: E rosette preparation stained for acid phosphatase. The positively staining tumour cell does not rosette in contrast to the negatively staining lymphocyte. Acid phosphatase $\times 1000$

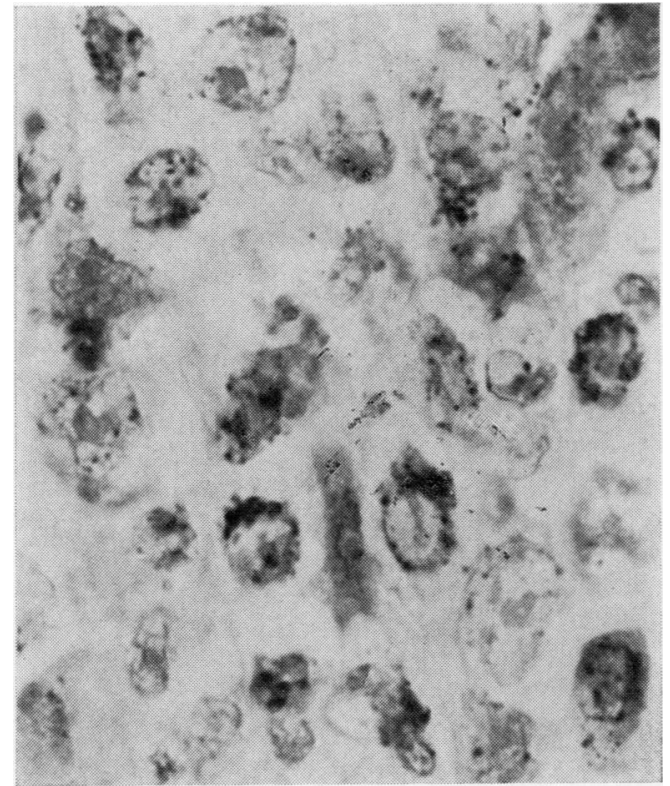

Fig. 7 Case 2: section of intestinal tumour stained for alpha-1-antitrypsin. There is granular staining of tumour cells often concentrated in a focus close to the nucleus. Immunoperoxidase $\times 1000$ 
doubt of the histiocytic origin of the malignant cells in the three cases we describe in this paper since they failed to form $E$ rosettes, showed $F c \gamma$ surface receptors and stained diffusely for NSE and acid phosphatase with inhibition of NSE staining by $\mathrm{NaF}$ in two of the cases. The identity of the cells in case 1 is further confirmed by their failure to react with two monoclonal antibodies to $T$ cells and their positive reaction with monoclonal anti Ia-like antibody (DA 2) in the absence of surface immunoglobulin. The demonstration of phagocytosis both in tissue sections ${ }^{3}$ and cell suspensions ${ }^{19}$ has been stressed as a property of malignant histiocytes. While we have frequently observed phagocytosis in sections of $\mathrm{MHI}^{2}$ this has by no means been an invariable finding in our cases. Phagocytosis tends to be observed in better differentiated cells, and its presence is quite inconstant. In case 2 for example, there was no hint of phagocytosis in any of the surgically removed tumour tissue but it was floridly present in necropsy sections. While we do not specifically test for phagocytosis in cell suspensions we might have expected to observe it in rosetted preparations, particularly those utilising IgG-coated ox RBC. Just as the demonstration of phagocytosis is not incontrovertible evidence for the histiocytic nature of malignant cells, ${ }^{17}$ neither, in our view, does the failure to demonstrate it exclude a histiocytic malignancy.

The considerable clinical and pathological differences between the three cases reported here emphasise the wide clinical spectrum of this disease and the great variation in both its macroscopic and microscopic appearances. ${ }^{19}$ Identification of the histiocytic nature of the malignant cells is, thus, central to the concept that MHI is a specific entity associated with coeliac disease. While this is best achieved using fresh material, difficulty in obtaining fresh specimens has led us to search for reliable immunohistochemical markers of macrophages that could be applied to formalin-fixed paraffin-embedded tissues from these cases. We have found that positive staining for $\alpha_{1}-\mathrm{AT}$, as demonstrated in these three cases, is a highly reliable and specific marker of benign and malignant histiocytes. ${ }^{8}$ This material which has been shown to be synthesised by monocyte/macrophage cells ${ }^{8} 20$ is found consistently in the tumour cells of MHI.

As well as providing confirmatory evidence of their histiocytic derivation these cases strongly support the suggestion that the villous atrophy in MHI is indicative of true coeliac disease, rather than a secondary response to the malignant neoplasm. There was objective evidence of gluten sensitivity in case 1 and the long history of recurrent iron deficiency anaemia in case 2 is characteristic of coeliac disease. We would stress the importance of obtaining fresh tissue from more of these cases, not only to verify the above findings but also to permit cytogenetic studies and to search for possible associated viruses.

We are grateful to Dr John Howell of Poole General Hospital for help in obtaining tissue from case 1 , and to Dr W Hindle for permission to publish this case. We are also grateful to Mr R Lane of the Royal Hampshire County Hospital, Winchester, for help in obtaining fresh tissue from case 2 and his permission to publish the case.

\section{References}

${ }^{1}$ Isaacson P, Wright DH. Intestinal lymphoma associated with malabsorption. Lancet $1978 ; \mathrm{i}: 67-70$.

${ }^{2}$ Isaacson P, Wright DH. Malignant histiocytosis of the intestine. Hum Pathol 1978;9:661-77.

${ }^{3}$ Byrne GE, Rappaport H. Malignant histiocytosis. In: Akazaki K, Rappaport C, Berard CW et al, eds. Malignant disease of the hamatopoietic system. Gann monograph on cancer research 15 Tokyo: University of Tokyo Press, $1973 ; 145-62$.

${ }^{4}$ Lukes RJ. The immunologic approach to the pathology of malignant lymphomas. Am J Clin Pathol 1979;72: 657-69.

5 Isaacson P. Malignant histiocytosis of the intestine. The early histological lesion. Gut 1978;21:381-6.

${ }^{6}$ Mepham BL, Frater W, Mitchell BS. The use of proleolytic enzymes to improve Ig staining by the PAP technique. Histochem $J$ 1979;11:345-57.

7 Isaacson P. Immunochemical demonstration of $\mathbf{J}$ chain: a marker of B-cell malignancy. J Clin Pathol 1979;32: 802-7.

${ }^{8}$ Isaacson P, Jones DB, Sadler GHM, Judd MA, Payne SW. Alpha-1 antitrypsin in human macrophages. $J$ Clin Pathol 1981;34:982-40.

${ }^{9}$ Stein H, Bonk A, Tolksdorf G, Lennert K, Rodt $H$, Gerdes J. Immunohistologic analysis of the organisation of normal lymphoid tissue and non-Hodgkin's lymphomas. J Histochem Cytochem 1980;28:746-60.

${ }^{10}$ Beverly PCL, Calland RG. Destructive functional characteristics of human ' $T$ ' lymphocytes defined by E rosetting or a monoclonal anti-T cell antibody. Eur J Immunol (in press).

${ }^{11}$ Brodsky FM, Parham P, Barnstaple CJ, Crumpton MJ, Bodmer WF. Monoclonal antibodies for the analysis of the HLA system. Immunol Rev 1979;47:3-61.

12 Payne SV, Jones DB, Haegert DG, Smith JL, Wright DH. $T$ and $B$ lymphocytes and Reed-Sternberg cells in Hodgkin's disease, lymph nodes and spleen. Clin Exp Immunol 1976;24:280-6.

${ }^{13}$ Payne SV, Newell DG, Jones DB, Wright DH. The ReedSternberg cell/lymphocyte interaction. Ultrastructure and characteristics of binding. Am J Pathol 1980;100: 7-24.

${ }^{14}$ Yam LT, Li CY, Crosby WH. Cytochemical identification of monocytes and granulocytes. Am J Clin Pathol 1971; $55: 283$.

${ }^{15}$ Hayhoe FGJ. Leucocyte cytochemistry. ACP Broadsheet 96, 1981.

${ }^{16}$ Grossi CE, Webb SR, Zicca A, et al. Morphological and histochemical analyses of two human $T$ cell subpopulations bearing receptors for IgM or IgG. $J$ Exp 
Med 1978;147:1405-17.

${ }^{17}$ Kadin ME, Kamoun M, Lamberg J. Erythrophagocytic T $\gamma$ lymphoma. A clinicopathologic entity resembling malignant histiocytosis. $N$ Engl J Med 1981 ;304:648-53.

18 Jaffe ES, Braylan RC, Nanba K, Frank MM, Berard CW. Functional markers: a new perspective on malignant lymphomas. Cancer Treat Rep 1977;61:953-62.

19 Isaacson P, Wright DH. Malabsorption and intestinal lymphomas. In Wright $\mathrm{R}$, ed. Recent advances in gastrointestinal pathology. London: WB Saunders, 1980:12.
${ }^{20}$ Wilson GB, Walker JH, Watkins Jnr. JH, Wolgroch D. Determination of subpopulations of leukocytes involved in the synthesis of al-antitrypsin in vitro (40832). Proc Soc Exp Biol Med 1980;164:105-14.

Requests for reprints to: Dr P Isaacson Department of Pathology, Level E, South Laboratory Block, General Hospital, Southampton SO9 4XY, England.

\section{Reports and Bulletins prepared by the Association of Clinical Biochemists}

The following reports and bulletins are published by the Association of Clinical Biochemists. They may be obtained from The Publishing Department, British Medical Journal (ACB Technical Bulletins), BMA House, Tavistock Square, London WCIH 9JR. Overseas readers should remit by British Postal or Money Order.

SCIENTIFIC REVIEWS (price $£ 1 \cdot 00 / \$ 2.00$ each)

1 The assessment of thyroid function March 1971 FV FLYNN and JR HOBBS

2 Renal function tests suitable for clinical practice January 1972 FL MITCHELL, N VEALL, and RWE WATTS

3 Biochemical tests for the assessment of fetoplacental function May 1975 CE WILDE and RE OAKEY

4 Test of exocrine pancreatic function March 1977 AH GOWENLOCK

5 Assay of cholinesterase in clinical chemistry March 1979 ELSIE SILK, J KING, and MARY WHITTAKER

\section{TECHNICAL BULLETINS (price $£ 1 \cdot 00 / \$ 2.00$ each)}

22 Bilirubin standards and the determination of bilirubin by manual and technicon AutoAnalyzer methods January 1971 BARBARA BILLING, RUTH hASLAM, and N WALD

23 Interchangeable cells for spectrophotometers and fluorimeters September 1971 Ss BROWN and AH GOWENLOCX

24 Simple tests to detect poisons March 1972 BW MEADE et al.

25 Blood gas analysers May 1972 K DixoN

26 Kits for enzyme activity determination September 1972 SB ROSALKI and D TARLOW

27 Assessment of pumps suitable for incorporation into existing continuous flow analytical systems November 1972 A FLECK $e t$ al.

28 Routine clinical measurements of transferrin in human serum September 1973 K DIXON
29 Control materials for clinical biochemistry (5th edition) September 1973 JF STEVENS

30 Notes on the quality of performance of serum cholesterol assays September 1973 SS BROWN

31 Determination of uric acid in blood and in urine July 1974 RWE IVATTS

32 A survey of amino acid analysers readily available in the United Kingdom September 1974 JE CARLYLE and P PURKISS

33 Definitions of some words and terms used in automated analysis November 1974 A FLECK, R ROBINSON, SS BROWN, and JR HOBBS

34 Measurement of albumin in the sera of patients January 1975 LINDA SLATER, PM CARTER, and JR HOBBS

35 Investigation of the validity of temperature correction factors for serum aspartate and alanine transaminases March 1975 SB ROSALKI et al.

36 Factors influencing the assay of creatinine November 1975 JGH COOK

37 A survey of enzyme reaction rate analysers readily available in the United Kingdom July 1977 RA SAUNDERS and RF BURNS

38 Transport of specimens for clinical chemistry analysis November 1977 P IVILDING, JF ZILVA, and CE WILDE

39 A scheme for the evaluation of diagnostic kits May 1978 PH LLOYD

40 A practical guide to gamma-counting in radioimmunoassay January 1980 CE WILDE and D OTTEWELL 41 The use of biochemical tests in the diagnosis ef disorders of calcium metabolism July 1980 ANGELA FAIRNEY 